\title{
ANTIOXIDANT PROPERTIES OF CRUDE AND COLD ETHANOL PRECIPITATED PROTEIN FROM PALM KERNEL CAKE (PKC) AS POTENTIAL COSMECEUTICAL AGENT
}

\author{
CHOI, W C*; HON, W M**; MOHAMAD, M; KOK, A K D X‡; LAI, K S ${ }^{\ddagger}$ and YAP, W S*
}

\begin{abstract}
Palm kernel cake (PKC) is a by-product obtained from the production of edible oils using oil palm (Elaeis guineensis). PKC is well-known for its high protein content, therefore, it was chosen as the target of this research to study its antioxidant properties, which is an important criteria in cosmeceutical industry. Our studies showed that, the extraction of crude protein at $80^{\circ} \mathrm{C}$ resulted in the highest total phenolic content (TPC) and protein yield. It was further seen that precipitation using $80 \%$ cold ethanol following protein extraction at $80^{\circ} \mathrm{C}$ gave the best protein yield of $56.6 \%$. The antioxidative activity of this precipitated protein was expressed as $I C_{50}$ for 1-diphenyl 1-2-picrylhydrazyl (DPPH) radical-scavenging capacity (517 $\left.\pm 0.016 \mathrm{mg} \mathrm{ml}^{-1}\right), 2$, 2'-azino-bisC3-ethylbenzothia zoline-6-sulphonic acid (ABTS) radical-scavenging capacity $\left(0.047 \pm 0.009 \mathrm{mg} \mathrm{ml}^{-1}\right)$ and ferrous ion-chelating (FIC) ability $\left(21 \pm 0.13 \mathrm{mg} \mathrm{ml}^{-1}\right)$. Meanwhile, the reducing power and TPC were $0.156 \pm 0.006$ trolox equivalent antioxidant capacity (TEAC) mmol $\mathrm{g}^{-1} \mathrm{dry}$ weight $(D W)$ and $25.10 \pm 0.58$ gallic acid equivalent $(G A E) \mu g g^{-1} D W$ respectively. The Pearson correlation test further revealed a significantly moderate to strong positive relationships between antioxidant properties with protein content and antioxidant properties with TPC. Taken together, both, the crude and precipitated protein obtained from PKC showed substantial amount of antioxidative activities, which could be used as sustainable source of antioxidant peptides in enhancing the quality of cosmeceutical products.
\end{abstract}

Keywords: antioxidant properties, cosmeceutical, crude protein, palm kernel cake, precipitated protein.

Date received: 25 April 2018; Sent for revision: 21 May 2018; Received in final form: 17 July 2018; Accepted: 3 January 2019

\section{INTRODUCTION}

Palm kernel cake (PKC), also known as palm kernel meal $(\mathrm{PKM})$, is one of the most abundant

* Department of Biotechnology, Faculty of Applied Sciences, UCSI University, 1 Jalan Puncak Menara Gading,

Taman Connaught, 56000 Kuala Lumpur, Malaysia. E-mail: wsyap@ucsiuniversity.edu.my

** Vice-Chancellor's Office, KDU University College, SS 22/41, Damansara Jaya,47400 Petaling Jaya, Selangor, Malaysia.

‡ University Council, UCSI University, 1 Jalan Puncak Menara Gading, 56000 Kuala Lumpur, Malaysia.

拉Department of Cell and Molecular Biology, Faculty of Biotechnology and Biomolecular Sciences, Universiti Putra Malaysia, 43400 UPM Serdang, Selangor, Malaysia. by-products of edible oils obtained from oil palm (Elaeis guineensis) after extraction. According to Malaysian palm oil statistics (MPOB, 2014), PKC is produced annually in large quantities, with about 1.8 million tonnes of PKC left over from the oil extraction process in the oil palm industry. This figure alone has attracted huge potential interest of PKC as a bioresource of raw material in many industries, especially those utilising PKC for its high protein content (Iluyemi et al., 2006) like animal feed (Arifin et al., 2009).

Cosmeceuticals are topical cosmeticpharmaceutical hybrids which lie on the spectrum between drugs and cosmetics (Lintner et al., 2009). One of the aims of cosmeceutical products is to improve the antioxidant properties of the skin, hence 
retarded the ageing process. Recently, the evolutions of antioxidative peptides which possess low molecular weight, easy absorption and high activity have drawn the attention of many researchers (Nakajima et al., 2008; Xie et al., 2008). Antioxidant peptides are peptides with antioxidative effect. It has advantages of being simpler in structure and more stable compared to other antioxidative enzymes. In addition, antioxidant peptides can react in human body without dangerous immunoreaction (Xie et al., 2008). These peptides also exhibit numerous bioactivities, such as inhibition of biomacromolecules peroxidation and elimination of free radicals produced in vivo (Xie et al., 2008).

Large quantities of PKC by-product are being produced annually in Malaysia from the oil palm plantations, and because this by-product has a high crude protein content, it would be valuable if this by-product could be transformed into new and non-conventional source of proteins such as cosmeceutical peptides (Arifin et al., 2009). Therefore, the aim of this study is to evaluate PKC as a potential valuable source of peptides to be used as cosmeceutical agent.

\section{MATERIALS AND METHODS}

\section{PKC Extraction}

The dry powder of PKC was purchased from ACE Edible Oil Industries Sdn Bhd, Malaysia. Then, it was ground and passed through 1.18 $\mathrm{mm}$ mesh sieve before it was used for extraction. PKC protein extraction was carried out using the method described by Arifin et al. (2009) with slight modifications. Approximately $75 \mathrm{~g}$ of mashed PKC were mixed with $750 \mathrm{ml}$ of 0.03 $\mathrm{M}$ sodium hydroxide $(\mathrm{NaOH}) \mathrm{pH} 12$ solution at $25^{\circ} \mathrm{C}, 60^{\circ} \mathrm{C}$ and $80^{\circ} \mathrm{C}$, respectively and stirred continuously at $150 \mathrm{rpm}$ for $4 \mathrm{hr}$. The $\mathrm{NaOH}$ : PKC ratio was 10:1 $\left(\mathrm{v} \mathrm{w}^{-1}\right)$. To precipitate PKC protein, modified method described by Moure et al. (2001) was used. Briefly, $50 \mathrm{ml}$ of crude protein was mixed with $12.5 \mathrm{ml}$ of cold ethanol $(20 \%)$ at $0^{\circ} \mathrm{C}$. The mixture was centrifuged at $11200 \mathrm{~g}$ for $7 \mathrm{~min}$. The pellet collected was air-dried and the supernatant was used in subsequent precipitation with $40 \%, 60 \%$ and $80 \%$ cold ethanol, in succession. The protein content was further determined using the Bradford method (Bradford, 1976) and the protein yield was calculated as follows: protein yield $(\%)=$ (protein obtained after precipitation/initial protein content) x $100 \%$.

\section{Biochemical Assay}

The total phenolic content of crude protein and ethanol precipitated samples were determined using a Folin-Ciocalteu (FC) assay as described by $\mathrm{Li}$ et al. (2008). Antioxidants properties were determined based on previously described methods of 1,1-diphenyl-2-picrylhydrazyl (DPPH) radicalscavenging capacity (Cai et al., 2006), 2,2'-azino-bis (3-ethylbenzothiazoline-6-sulphonic acid) (ABTS) radical-scavenging capacity (Guimaraes et al., 2007) and ferric reducing ability of plasma (FRAP) assay (Benzie and Strain, 1996). The ferrous ion-chelating (FIC) assay reported by Chan et al. (2008) was adopted. The ability of the extracts to chelate ferrous ions was calculated as follows: chelating effect \% $=\left(1-\mathrm{A}_{\text {sample }} / \mathrm{A}_{\text {control }}\right) \times 100$.

\section{Statistical Analysis}

All crude PKC extractions and ethanol precipitation of the crude PKC extracts were carried out in three independent experiments. The results were presented as mean \pm SEM (standard error mean). GraphPad Prism (Version 5, GraphPad Software Inc., USA) was used to calculate the inhibitory concentration $50 \%\left(\mathrm{IC}_{50}\right)$ values of the DPPH, ABTS and FIC assays, whereas IBM SPSS Statistics software (Version 19, IBM Corporation, USA) was used to perform an analysis of variance (ANOVA) and Tukey's Multiple Comparison (TMC) test at 95\% significance level. A Pearson correlation test was then conducted to determine the strength of correlation between the different antioxidant activities and both with (i) the protein yield and (ii) the total phenolic content (TPC).

\section{RESULTS}

The protein content of PKC increased when the extraction temperature used increased (Table 1). The protein content of PKC ranged between $0.177 \pm 0.007$ $\mathrm{mg} \mathrm{g}^{-1}$ dry weight (DW) and $0.502 \pm 0.006 \mathrm{mg} \mathrm{g}^{-1} \mathrm{DW}$. A 1.5-fold increase in protein was observed when the extraction temperature was raised from $25^{\circ} \mathrm{C}$ to $60^{\circ} \mathrm{C}$, while a 2.8 -fold increase was observed when the temperature was raised from $25^{\circ} \mathrm{C}$ to $80^{\circ} \mathrm{C}$.

The antioxidant properties of PKC extracts were assessed using DPPH and ABTS scavenging assays, metal chelating assay and ferric reducing power. Of all the three extraction temperatures used, $80^{\circ} \mathrm{C}$ yielded the best results for all antioxidant assays $\left[\left(\mathrm{IC}_{50}\right.\right.$ value of $\mathrm{DPPH}$ assay $=0.774 \pm 0.019 \mathrm{mg} \mathrm{ml}^{-1} ; \mathrm{IC}_{50}$ value of ABTS assay $=0.055 \pm 0.001 \mathrm{mg} \mathrm{ml}^{-1}$ and FRAP assay $=0.67 \pm 0.02$ trolox equivalent antioxidant capacity (TEAC) mmol g-1] except for metal chelating effect (IC value of FIC assay $=5.04 \pm 0.15 \mathrm{mg} \mathrm{ml}^{-1}$ ) (Table 1). On the other hand, TPC was recorded between $54.62 \pm 0.98$ and $67.70 \pm 0.72$ gallic acid equivalent (GAE) $\mu \mathrm{g} \mathrm{g}^{-1} \mathrm{DW}$. The PKC extracted at $80^{\circ} \mathrm{C}$ had the highest TPC. No significant difference in TPC 
TABLE 1. EFFECTS OF EXTRACTION TEMPERATURE ON PROTEIN CONTENT, ANTIOXIDANT PROPERTIES AND TOTAL PHENOLIC CONTENT FROM PALM KERNEL CAKE

\begin{tabular}{|c|c|c|c|c|c|c|}
\hline $\begin{array}{c}\text { Extraction } \\
\text { temperature } \\
\left({ }^{\circ} \mathrm{C}\right)\end{array}$ & $\begin{array}{c}\begin{array}{c}\text { Protein } \\
\text { content } \\
\left(\mathrm{mg} \mathrm{g}^{-1} \mathrm{DW}\right)\end{array}\end{array}$ & $\begin{array}{c}\mathrm{IC}_{50} \text { of } \\
\text { DPPH assay } \\
\left(\mathrm{mg} \mathrm{ml}^{-1}\right)\end{array}$ & $\begin{array}{c}\mathrm{IC}_{50} \text { of } \\
\text { ABTS assay } \\
\left(\mathrm{mg} \mathrm{ml}^{-1}\right)\end{array}$ & $\begin{array}{c}\mathrm{IC}_{50} \text { of } \\
\text { FIC assay } \\
\left(\mathrm{mg} \mathrm{ml} \mathrm{ml}^{-1}\right)\end{array}$ & $\begin{array}{c}\text { FRA assay } \\
\text { (TEAC } \\
\left.\text { mmol g }{ }^{-1} \mathrm{DW}\right)\end{array}$ & $\begin{array}{c}\text { Total } \\
\text { phenolic content } \\
\left(\text { GAE } \mu \mathrm{g} \mathrm{g}^{-1} \mathrm{DW}\right)\end{array}$ \\
\hline 25 & $0.177 \pm 0.007^{\S}$ & $1.676 \pm 0.046^{*}$ & $0.086 \pm 0.002^{*}$ & $2.38 \pm 0.03^{\ddagger}$ & $0.52 \pm 0.02^{\ddagger}$ & $57.16 \pm 0.66^{\ddagger}$ \\
\hline 60 & $0.266 \pm 0.007^{\ddagger}$ & $1.412 \pm 0.022^{\ddagger}$ & $0.068 \pm 0.003^{\ddagger}$ & $4.18 \pm 0.11^{*}$ & $0.47 \pm 0.02^{\ddagger}$ & $54.62 \pm 0.98^{\ddagger}$ \\
\hline 80 & $0.502 \pm 0.006^{*}$ & $0.774 \pm 0.019 \S$ & $0.055 \pm 0.001^{\S}$ & $5.04 \pm 0.15^{\star}$ & $0.67 \pm 0.02^{*}$ & $67.70 \pm 0.72^{*}$ \\
\hline
\end{tabular}

Note: Mean $\pm S E M,{ }^{*} \neq \S$ Within a column, values shown with different superscript symbols are significantly different $(p<0.05)$. DW - dry weight.

DPPH - 1-diphenyl-2-picrylhydrazyl.

ABTS - 2, 2'-azino-bis (3-ethylbenzothiazoline-6-sulphonic acid).

FIC - ferrous ion-chelating

TEAC - trolox equivalent antioxidant capacity.

GAE - gallic acid equivalent.

FRAP - ferric reducing ability of plasma.

was found between extraction temperatures of $25^{\circ} \mathrm{C}$ and $60^{\circ} \mathrm{C}$, whereas an increase of about $24 \%$ was observed at $80^{\circ} \mathrm{C}$. Further comparison between the protein yield and TPC of PKC extracted at $80^{\circ} \mathrm{C}$ demonstrated that the protein yield was about 6.4fold higher than the TPC. This suggests that protein which is abundantly found in PKC sample extract is responsible for most of the antioxidant activities occurring in this study. Since PKC sample extracted at $80^{\circ} \mathrm{C}$ demonstrated the highest protein yield and high antioxidant activities, this condition was used for the subsequent precipitation process using cold ethanol.

When the precipitation was carried out using $40 \%$ cold ethanol, no precipitate was obtained. Therefore, no data was tabulated for PKC precipitated at this percentage. With regard to protein yield (Table 2), 80\% cold ethanol precipitation gave the highest protein yield of about $57 \%$, which was 27.5-fold and 5.3-fold higher than 20\% and 60\% cold ethanol precipitation, respectively. Meanwhile, antioxidant activities of PKC protein precipitated at $80 \%$ cold ethanol showed lower $\mathrm{IC}_{50}$ for $\mathrm{DPPH}$ and
ABTS assays and higher FRAP activity as compared to $20 \%$ and $60 \%$ cold ethanol precipitates. On the other hand, no significant difference was observed in terms of FIC assay for $80 \%$ and $60 \%$ cold ethanol precipitates. Antioxidant activities of precipitated PKC protein at $80 \%$ was improved as compare to crude protein with reduction of 33\% (DPPH), 15\% (ABTS) and $56 \%$ (FIC) of $\mathrm{IC}_{50}$ respectively. The FRAP assay also showed an approximate reduction of $76 \%$ of antioxidant activity for $80 \%$ cold ethanol precipitation as compared to crude extract, revealing the loss of antioxidant protein towards the ferric reducing antioxidant power.

Besides, an increase in the TPC was obtained when crude PKC protein was precipitated with increasing concentrations of cold ethanol, where the highest amount was $25.10 \pm 0.58 \mathrm{GAE}_{\mu \mathrm{g} \mathrm{g}} \mathrm{g}^{-1} \mathrm{DW}$. This result demonstrated that besides protein, a part of the phenolic compound was also being precipitated using cold ethanol. However, when compared with crude protein extract, a reduction of $63 \%$ of TPC was observed. Subsequent analysis revealed a significant moderate to strong positive correlations (from 0.519

TABLE 2. PROTEIN YIELD, ANTIOXIDANT PROPERTIES AND TOTAL PHENOLIC CONTENT FROM COLD ETHANOL PRECIPITATED PROTEIN OF PALM KERNEL CAKE EXTRACTED AT $80^{\circ} \mathrm{C}$

\begin{tabular}{|c|c|c|c|c|c|c|}
\hline $\begin{array}{l}\text { Cold ethanol } \\
\text { precipitated } \\
\text { protein }(\%)\end{array}$ & $\begin{array}{l}\text { Protein } \\
\text { yield } \\
(\%)\end{array}$ & $\begin{array}{c}\mathrm{IC}_{50} \text { of } \\
\text { DPPH assay } \\
\left(\mathrm{mg} \mathrm{ml}^{-1}\right)\end{array}$ & $\begin{array}{c}\mathrm{IC}_{50} \text { of } \\
\text { ABTS assay } \\
\left(\mathrm{mg} \mathrm{ml}^{-1}\right)\end{array}$ & $\begin{array}{c}\mathrm{IC}_{50} \text { of } \\
\text { FIC assay } \\
\left(\mathrm{mg} \mathrm{ml}^{-1}\right)\end{array}$ & $\begin{array}{c}\text { FRAP assay } \\
\text { (TEAC mmol } \\
\left.\mathrm{g}^{-1} \mathrm{DW}\right)\end{array}$ & $\begin{array}{l}\text { Total } \\
\text { phenolic content } \\
\left(\mathrm{GAE} \mu \mathrm{g} \mathrm{g}^{-1} \mathrm{DW}\right)\end{array}$ \\
\hline 60 & $8.8 \pm 0.02^{\ddagger}$ & $1.493 \pm 0.074^{\ddagger}$ & $0.248 \pm 0.009^{\ddagger}$ & $2.19 \pm 0.08^{*}$ & $0.025 \pm 0.001^{\ddagger}$ & $3.54 \pm 0.09^{\ddagger}$ \\
\hline 80 & $56.6 \pm 0.06^{*}$ & $0.517 \pm 0.016^{\S}$ & $0.047 \pm 0.009^{\S}$ & $2.21 \pm 0.13^{*}$ & $0.156 \pm 0.006^{*}$ & $25.10 \pm 0.58^{*}$ \\
\hline
\end{tabular}

Note: Mean $\pm S E M,{ }^{*}{ }^{*}$ Within the column, the same superscript symbols indicates no significant difference $(p<0.05)$, NA - not available.

DW - dry weight.

DPPH - 1-diphenyl-2- picrylhydrazyl.

ABTS - 2, 2'-azino-bis (3-ethylbenzothiazoline-6-sulphonic acid).

FIC - ferrous ion-chelating.

TEAC - trolox equivalent antioxidant capacity.

GAE - gallic acid equivalent. 
to 0.995$)$ for both protein yield and TPC with the antioxidant activities measured $(\mathrm{p}<0.01)$ (Table 3$)$. Moderate positive correlation was observed in FIC assay [0.545 for bovine serum albumin (BSA) while 0.519 for TPC]; whereas strong positive correlations were observed for DPPH (0.721 for BSA while 0.707 for TPC), ABTS (0.783 for BSA while 0.770 for TPC) and FRAP (0.989 for BSA while 0.995 for TPC) (Table 3). Positive correlations were also demonstrated for both protein content (BSA) and TPC obtained from cold ethanol precipitated PKC with antioxidant activities, whereby their $r$ values were very close to each other. or non-protein substances with chelating abilities in the PKC sample extracts. According to Zhu et al. (2014), high temperature may lead to the change of protein secondary structure, thus leading to lower metal chelating activity. Meanwhile, TPC increases when the extraction temperature increases. When higher temperature was used, the cell wall integrity of the samples might weaken, resulting in more polyphenols migrating into the solvent (Spigno et al., 2007).

Further protein precipitation using various percentage of cold ethanol revealed that protein yield improved as the ethanol percentage increased.

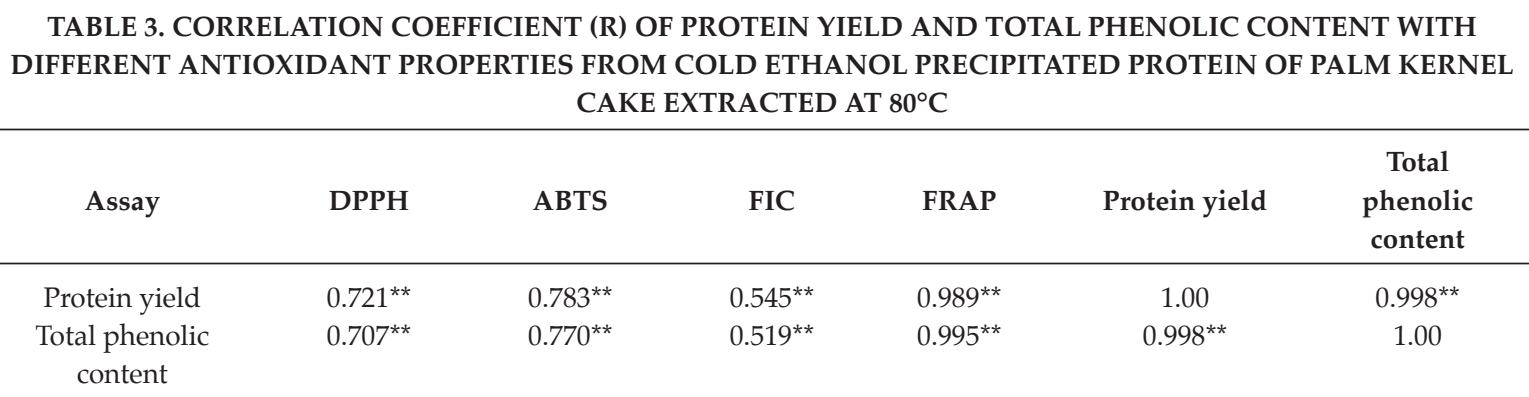

Note: ${ }^{* *}$ Correlation is significant at the 0.01 level (2-tailed).

DPPH - 1-diphenyl-2- picrylhydrazyl.

ABTS - 2, 2'-azino-bis (3-ethylbenzothiazoline-6-sulphonic acid)

FIC - ferrous ion-chelating.

FRAP - ferric reducing ability of plasma.

\section{DISCUSSION}

This study showed that the protein yield is correlated with the increase in extraction temperature. At higher temperature, the degradation of protein macromolecules might take place leading to smaller molecular weight peptides with higher solubility, thus increasing the protein yield (Ortiz and Wagner, 2002). In the cosmeceutical field, the smaller molecular weight peptides have a major advantage in that these molecules tend to have a better diffusivity in skin, especially those peptides with 500 Da or lesser (Gorouhi and Maibach, 2009). In addition, more small molecules are believed to be present (indicated by high protein yield) at $80^{\circ} \mathrm{C}$, which leads to a higher probability of these molecules having the ability to access the binding sites of the free radicals in DPPH and ABTS assays, compared to those proteins extracted at $25^{\circ} \mathrm{C}$ and $60^{\circ} \mathrm{C}$, respectively. The results are also consistent with the study done by Teixeira et al. (2012) on Mentha pulegium whereby hot water extract gave the highest $\mathrm{DPPH}$ free radical scavenging activity $\left(\mathrm{EC}_{50}=16.3\right.$ $\pm 0.4 \mu \mathrm{g} \mathrm{ml}^{-1}$ ). In contrast, a lower chelating ability (FIC) was observed on PKC samples extracted at $80^{\circ} \mathrm{C}$. This might be due to the degradation of protein
At high ethanol concentrations, more proteins are precipitated due to a decrease in solvating power of water for a charged hydrophilic protein molecule. On the ethanol solvent itself, this can be explained in terms of the reduction of the dielectric constant, or simply the bulk displacement of water owing to partial immobilisation of water molecules through hydration of the organic solvent (Scopes 1994). Moreover, higher antioxidative activity was also detected on PKC protein precipitated at $80 \%$ cold ethanol.

Analysis of correlation coefficient $(r)$ of protein yield and TPC with different antioxidant activities showed significantly moderate to strong positive correlation. Previous studies have shown that the antioxidant activities measured depended mainly on the TPC (Kiselova et al., 2006; Silva et al., 2007) which is in agreement with the result obtained from our analysis. In addition, recent study by Chang et al. (2014) on protein hydrolysates produced from oil palm kernel showed that significant positive correlations were found between the protein content of oil palm kernel hydrolysates $(\mathrm{OPKH})$ and the $\mathrm{ABTS}^{\bullet+}$ scavenging activities and OPKH with FRAP, which is similar with this study. The size and amino acid sequence of peptides contributed to the unique 
chemical composition and physical properties of proteins, which play an important role to increase the antioxidant capacity (Elias et al., 2008). Thus, it can be deduced that the cold ethanol precipitated protein from PKC in this study could contain such proteins or peptides which conferred the antioxidant activities. Although both protein content and TPC showed positive correlations with the antioxidant activities measured, nevertheless further research on purification is needed to eliminate or minimise the interference of other potentially antioxidative constituents.

\section{CONCLUSION}

In summary, alkaline extraction of $\mathrm{PKC}$ at $80^{\circ} \mathrm{C}$ gave the highest protein content as well as antioxidative activities. Using cold ethanol precipitation, protein pellet precipitated at $80 \%$ demonstrated satisfactory protein recovery of about $56 \%$, and better antioxidative properties for most assays, except FRAP when compared to crude protein. Our study showed significant positive correlations between protein content and TPC with antioxidant activities, thus depicting PKC as a promising source of proteins as well as non-protein based substances with highly effective antioxidative components to be used in cosmeceutical products. This study revealed the potential uses of PKC as a valuable and sustainable source of cosmeceutical additive or component for cosmeceutical industry.

\section{ACKNOWLEDGEMENT}

The authors would like to express their sincere appreciation for the grant provided by UCSI University Research Grant (Proj-in-FAS-002) to carry out this project.

\section{REFERENCES}

Arifin, B; Bono, A; Farm, Y Y; Ling, A L L and Fui, S $Y$ (2009). Protein extraction from palm kernel meal. J. Appl. Sci., 9: 2996-3004.

Benzie, I F F and Strain, J J (1996). The ferric reducing ability of plasma (FRAP) as a measure of 'antioxidant power': The FRAP assay. Anal. Biochem., 239: 70-76.

Bradford, M (1976). A rapid and sensitive method for the quantitation of microgram quantities of protein utilizing the principle of protein-dye binding. Anal. Biochem., 72: 248-254.

Cai, Y Z; Sun, M; Xing, J; Luo, Q and Corke, H (2006). Structure-radical scavenging activity relationship of phenolic compounds from traditional Chinese medicinal plants. Life Sci., 78: 2872-2888.

Chan, E W C; Lim, Y Y; Wong, L F; Lianto, F S; Wong, S K; Lim, K K; Joe, C E and Lim, T Y (2008). Antioxidant and tyrosinase inhibition properties of leaves and rhizomes of ginger species. Food Chem., 109: 477-483.

Chang, S K; Hamajima, H; Ismail, A; Yanagita, T; Esa, M N and Baharuldin, M T H (2014). Health promoting properties of protein hydrolysates produced from oil palm (Elaeis guineensis) kernel. Food Sci. Biotechnol., 23: 1279-1285.

Elias, R J; Kellerby, S S and Decker, E A (2008). Antioxidant activity of proteins and peptides. Crit. Rev. Food Sci. Nutr., 48: 430-441.

Gorouhi, F and Maibach, H I (2009). Role of topical peptides in preventing or treating aged skin. Int. J. Cosmetic Sci., 31: 327-345.

Guimaraes, C M; Giao, M S; Martinez, S S; Pintado, A I; Pintado, M E and Bento, L S (2007). Antioxidant activity of sugar molasses, including protective effect against DNA oxidative damage. Food Chem. Toxicol., 72: 39-43.

Iluyemi, F B; Hanafi, M M; Radziah, $\mathrm{O}$ and Kamarudin, M S (2006). Fungal solid state culture of palm kernel cake. Bioresource Techno., 97: 477-482.

Kiselova, Y; Ivanova, D; Chervenkov, T; Gerova, D; Galunska, B and Yankova, T (2006). Correlation between the in vitro antioxidant activity and polyphenol content of aqueous extracts from Bulgarian herbs. Phytother. Res., 20: 961-965.

Li, H B; Wong, C C; Cheng, K W and Chen, F (2008). Antioxidant properties in vitro and total phenolic contents in methanol extracts from medicinal plants. Lebensmittel-Wissenschaft and-Technol., 41: 385-390.

Lintner, K; Mas-Chamberlin, C; Mondon, P; Peschard, O and Lamy, L (2009). Cosmeceuticals and active ingredients. Clin. Dermatol., 27: 461-468.

Moure, F; Rendueles, M and Diaz, M (2001). Coupling process for plasma protein fractionation using ethanol precipitation and ion exchange chromatography. Meat Sci., 64: 391-398.

MPOB (2014). Economics and Industry Development Division. Accessed on 25 June 2017.

Nakajima, K; Yoshie-Stark, Y and Ogushi, M (2008). Comparison of ACE inhibitory and DPPH radical scavenging activities of fish muscle hydrolysates. Food Chem., 114: 844-851. 
Ortiz, S E M and Wagner, J R (2002). Hydrolysates of native and modified soy protein isolates: Structural characteristics, solubility and foaming properties. Food Res. Int., 35: 511-518.

Scopes, R K (1994). Separation by precipitation. Protein Purification: Principles and Practice (Scopes, $\mathrm{R}$ K ed.). Springer-Verlag, New York. p. 71-101.

Silva, E M; Souza, J N S; Rogez, H; Rees, J F and Larondelle, Y (2007). Antioxidant activities and polyphenolic contents of fifteen selected plant species from the Amazonian region. Food Chem., 101: 1012-1018.

Spigno, G; Tramelli, L and De Faveri, D M (2007). Effects of extraction time, temperature and solvent on concentration and antioxidant activity of grape marc phenolics. J. Food Eng., 81: 200-208.

Teixeira, B; Marques, A; Ramos, C; Batista, I; Serrano, C; Matos, O; Neng, N R; Nogueira, J M F; Saraiva, J A and Nunes, M L (2012). European pennyroyal (Mentha pulegium) from Portugal: Chemical composition of essential oil and antioxidant and antimicrobial properties of extracts and essential oil. Ind. Crop Prod., 36: 81-87.

Xie, Z J; Huang, J R; Xu, X M and Jin, Z Y (2008). Antioxidant activity of peptides isolated from alfalfa leaf protein hydrolysate. Food Chem., 111: 370-376.

Zhu, C Z; Zhang, W G; Kang, Z L; Zhou, G H and Xu, X L (2014). Stability of an antioxidant peptide extracted from Jinhua ham. Meat Sci., 96: 783-789. 